\title{
Histopathological and molecular features of lung cancer
}

\section{Akciğer kanserinin histopatolojik ve moleküler özellikleri}

\author{
Gülden DİNIZZ ${ }^{1}$, İsmet ÜNLÜ², Berna KÖMÜRCÜOĞLU \\ ${ }^{1}$ Tepecik Ĕ̆itim ve Araştırma Hastanesi, Patoloji, İzmir \\ ${ }^{2} \dot{I}_{z m i r}$ Katip Çelebi Üniversitesi, Atatürk Ĕ̆gitim ve Araştırma Hastanesi, Radyasyon Onkolojisi, İzmir \\ ${ }^{3}$ Dr. Suat Seren Göğüs Hastalıkları ve Cerrahisi Ĕ̆itim ve Araştırma Hastanesi, Gögüis Hastalıkları, İzmir
}

\section{ABSTRACT}

Lung cancer has been more frequently observed during the last 70 years. Many factors thought to be of pathogenic importance in the past are now considered to be totally unrelated or minimally related to cancer. The exposure to asbestosis, polycyclic aromatic hydrocarbons, nickel, arsenic, radon, and vinyl chloride are also responsible for carcinomas. But all of these factors become extremely unimportant when compared with the role played by smoking. Tobacco has a long history dating back to 600 A.D. It is known that Native Americans smoked tobacco for special religious and medical purposes. In 1964, the first report was published about the dangers of smoking and it was noticed that the nicotine and tar in cigarettes cause lung cancer. It is currently known that the smoke contains high levels of carcinogenic tobacco-specific nitrosamines. Therefore lung tumors that are histologically similar to the smoking-related lung cancers in humans do not develop in "non-smoker" animals.

Most cases of lung cancer are most frequently diagnosed at an advanced stage where only limited number of treatment alternatives can be offered to these patients. The development of lung cancer involves multiple phases of tumorigenesis including interactions among genetic, epigenetic, and environmental factors with resultant dysregulation of key oncogenes and tumor suppressor genes ending in activation of cancer-related signaling pathways. For years, lung cancers have been classified as small cell and non-small cell lung cancers and this classification was satisfactory for treatment. The past decade has witnessed the discovery of multiple molecules that are effective in the development of lung cancer which are more commonly detected in adenocarcinomas. Therefore in histopathological examination, special aim is placed on discriminating adenocarcinomas from the other lung cancers so as to effectively select tumors for targeted molecular testing.

Current review summarizes the histopathological features of lung cancers according to the 2015 World Health Organization (WHO) classification of lung cancer and attempts to focus on further understanding of the molecular abnormalities underlying lung cancer development and progression.

Key words: Lung cancer, molecular alterations, histopathologic classifications, targeted therapy

$\ddot{\mathbf{O Z Z}}$

\begin{abstract}
Akciğer kanseri son 70 yılda giderek daha fazla gözlenmektedir. Geçmişte tümör gelişiminde önemi olduğu düşünülen birçok faktör artık kanserle ilişkisiz ya da çok az etkili olarak değerlendirilmektedir. Asbest, polisiklik aromatik hidrokarbonlar, nikel, arsenik, radon ve vinil klorid benzeri maddelere maruz kalmak da kansere neden olmaktadır. Fakat tüm bunların önemi sigara içiminin rolüyle karşılaştırıldığında son derece silikleşmektedir. Tütünün tarihi M.S. 600 yılı kadar eskiye dayanmaktadır. Kızılderililerin dini veya medikal nedenlerle tütün içtikleri bilinmektedir. Sigaranın tehlikelerine ilişkin ilk makale ise 1964 yılında basılmış ve sigaradaki nikotin ile katranın kansere yol açtığına dikkat çekilmiştir. Sigara dumanı yüksek düzeyde tütüne özgü karsinojenik nitrozaminler içerir. Bu yüzden "sigara içmeyen" hayvanlarda, insanlardakine benzer sigarayla ilişkili akciğer tümörleri gelişmez.

Coğu akciğer kanseri, hastalara sınırlı tedavi seçeneği sunulabilecek ileri evrede tanı alır. Ákciğer kanseri gelişiminde; genetik, epigenetik ve çevresel faktörleri içeren ve anahtar role sahip onkogenlerle tümör supresör genlerin düzensiz etkileşimlerine bağlı kanserle ilişkili sinyal yolaklarının aktivasyonuna yol açan coklu kanserojenik aşamalar gözlenir. Yıllarca akciğer kanseri küçük hücreli ve küȩük hücreli dışı akciğer kanseri olarak sınıflanmış ve bu sınıflama tedavi için yeterli olmuştur. Son on yılda, akciğer kanser gelişiminde etkili birçok moleküler değisiklikler kesfedilmis olup, bunlar daha cok adenokarsinomlarda saptanmaktadır. Bu nedenle, histopatolojik incelemede özel olarak hedeflenmiş moleküler testlerin uygulanacağı tümörleri etkili bir şekilde belirleyebilmek için adenokarsinomun diğer akciğer karsinomlarından ayırt edilmesi amaçlanmaktadır.

Bu derleme, 2015 Dünya Sağık Örgütü (DSÖ) akciğer tümörleri sınıflamasına göre akciğer tümörlerinin histopatolojik özelliklerini özetlemeyi ve akciğer kanseri oluşup ilerlemesinin altında yatan moleküler anormallikleri irdelemeyi amaçlamaktadır.
\end{abstract}

Anahtar kelimeler: Akciğer kanseri, moleküler değişiklikler, histopatolojik sınıflama, hedefe yönelik tedavi
Alındığı tarih: 25.12 .2016

Kabul tarihi: 05.01.2017

Yazışma adresi: Doç. Dr. Gülden Diniz, Kıbrıs Şehitleri Cad. 51/11, Alsancak-35220-İzmir e-mail: agdiniz@windowslive.com 


\section{INTRODUCTION}

Lung cancer (LC), has been described as one of the most common cancers with a high mortality rate, and the leading cause of cancer-related death worldwide ${ }^{(1-3)}$. About $70 \%$ of lung cancers are inoperable, and in these patients, cytology or small biopsy specimens are the only available material for precise diagnosis and also for possible molecular assessments. Almost all LC cases are related with carcinomas and associated with smoking habit. Indeed, nearly $80 \%$ of all LC cases in men and $90 \%$ in women are associated with smoking ${ }^{(1)}$. During several decades, lung cancers have been classified into small cell lung cancers (SCLC) and non-small cell lung cancers (NSCLC) and lung carcinoid tumor. NSCLC has been accounted for approximately $80 \%$ of all LCs and include the subtypes of adenocarcinoma, squamous cell carcinoma (SCC), and large cell carcinoma, while SCLC has been accounted for approximately $15 \%$ of all newly diagnosed LC cases and has been strongly correlated with smoking habit ${ }^{(2)}$. SCLC is extremely aggressive with a high growth fraction and early metastatic spre$\operatorname{ad}^{(1-3)}$.

In recent years, the relative frequency of adenocarcinomas has increased, while SCC and SCLC have declined and currently the most frequent subtype is adenocarcinoma ${ }^{(2,3)}$. This purely morphological taxonomy has been challenged, because it has been recognized that somatic oncogenetic alterations can further subdivide these LC subtypes on molecular basis ${ }^{(1)}$.

Due to remarkable advances over the past decade in understanding lung cancer, particularly in the field of oncology and molecular biology, there is a pressing need for a revised classification, based not on pathology alone, but rather on an integrated multidisciplinary approach for classification of lung cancer. The 2015 World Health Organization (WHO) classification of lung tumors has just been published with some important modifications from the $2004 \mathrm{WHO}$ classification ${ }^{(2)}$. The revised, and greatly improved classification aids in further development of the field, increases the impact of research, improves patient care and predicts outcome. Although the 2015 WHO classification of lung tumors is still based on the histopathological features of tumors, the diagnosis of small samples, and molecular characterization of tumors have been greatly emphasized. The most significant change is in the approach to undifferentiated neoplasms which were classified as large cell carcinoma according to the 2004 WHO classification. Indeed, some undifferentiated tumors share similar molecular features with differentiated tumors, and owing to their immunohistochemical profile these tumors can be defined as a non-keratinizing SCC or solid-pattern adenocarcinoma. As a consequence, the category of large cell carcinoma will account for a much smaller proportion of tumors, where immunohistochemistry (IHC) is inconclusive or cannot be performed. The other striking differences are in the classification of adenocarcinomas. According to the 2015 WHO guidelines (Table 1), the category of adenocarcinoma includes the lepidic, acinar, papillary, micropapillary, solid, mucinous, colloid, fetal, and enteric subtypes. On the other hand, the terms of bronchioalveolar, signet-ring and clear cell carcinoma are no longer used. SCC has also been reclassified into keratinizing, nonkeratinizing, and basaloid subtypes together with the nonkeratinizing tumors requiring immunohistochemical confirmation of squamous differentiation. One of the most important change made in WHO 2015 is grouping of neuroendocrine tumors together with SCLC, large cell neuroendocrine carcinoma and carcinoid tumor ${ }^{(2-7)}$.

There are also some changes on the current viewpoint of histologic grading of LC. For example the entity "bronchioloalveolar carcinoma" (BAC) was abandoned. Although it was defined as adenocarcinoma in situ by the 1999 WHO classification, in practice, BAC is a confusing term which has been used in the literature for very different conditions, ranging from noninvasive to advanced adenocarcinomas. In WHO 2015 classification, the new entities "adenocarcinoma in situ" and "minimally invasive adenocarcinoma" have been introduced. They have an 
Table 1. 2015 WHO classification of epithelial lung tumors.

\begin{tabular}{|c|c|}
\hline Main Group & Subtypes \\
\hline Adenocarcinoma & $\begin{array}{l}\text { Lepidic, acinar, papillary, micropapillary, solid, mucinous, colloid, fetal, and enteric subtypes and minimally invasive, } \\
\text { preinvasive lesions (atypical hyperplasia and adenocarcinoma in situ) }\end{array}$ \\
\hline Squamous cell carcinoma & Keratinizing SCC, nonkeratinizing SCC, basaloid SCC and preinvasive lesion (SCC in situ) \\
\hline Neuroendocrine tumors & $\begin{array}{l}\text { Small cell carcinoma, large cell neuroendocrine carcinoma, carcinoid tumors (typical carcinoid and atypical carcinoid) } \\
\text { and preinvasive lesion (diffuse idiopathic pulmonary neuroendocrine cell hyperplasia) }\end{array}$ \\
\hline \multicolumn{2}{|r|}{$\mathrm{P}_{\mathrm{P}}$} \\
\hline \multicolumn{2}{|l|}{ Adenosquamous carcinoma } \\
\hline \multicolumn{2}{|l|}{ Pleomorphic carcinoma } \\
\hline \multicolumn{2}{|l|}{ Spindle cell carcinoma } \\
\hline \multicolumn{2}{|l|}{ Giant cell carcinoma } \\
\hline \multicolumn{2}{|l|}{ Carcinosarcoma } \\
\hline \multicolumn{2}{|l|}{ Pulmonary blastoma } \\
\hline Other and unclassified carcinoma & Lymphoepithelioma-like carcinoma, NUT carcinoma (presence of NUT gene rearrangement) \\
\hline Salivary gland type tumors & Mucoepidermoid carcinoma, adenoid cystic carcinoma, epithelial-myoepithelial carcinoma and pleomorphic adenoma \\
\hline Papillomas & Squamous cell papilloma, glandular papilloma and mixt type \\
\hline Adenomas & Sclerosing pneumocytoma, alveolar adenoma, papillary adenoma, musinous cystadenoma, mucous gland adenoma \\
\hline
\end{tabular}

(*) The table is copied from "2015 WHO classification of Lung tumors, the reference 2.

almost $100 \%$ cure rate if completely excised. The term "mixed adenocarcinoma" is abandoned, and invasive adenocarcinoma is classified according to the predominant pattern and in consideration of the percentages of the various patterns present. These different histologic patterns have prognostic significance, and in the presence of multiple tumors, they can be useful to discriminate multiple primaries from metastases. The WHO 2015 classification considers not only surgical specimens, but also cytologic specimens and small biopsy samples, with several practical suggestions on how to maximize the use of these materials ${ }^{(2,8)}$.

In this review, we aim to summarize the histopathological features of lung cancers according to the 2015 WHO classification of LC and to attempt to focus on further understanding of the molecular abnormalities underlying development and progression of lung cancer.

\section{Histopathological subtypes of lung cancers}

Recently encountered predominant histological types of LC are adenocarcinoma, SCC, small cell carcinoma (or according to the early nomenclature SCLC) and large cell carcinoma ${ }^{(2)}$. Smoking is associated with all of these types, but the strongest association is with SCC and SCLC. Basic histological and clinical features of current LC subtypes can be summarized as follows:

According to the WHO 2015 classification of LC, invasive adenocarcinoma is a malignant epithelial tumor with glandular differentiation, mucin production or pneumocyte marker expression. These tumors show an acinar, papillary, micropapillary, lepidic or solid growth pattern, with either mucin or pneumocyte marker expression. After comprehensive histological evaluation, these tumors are classified according to their predominant patterns. During the 1970s, adenocarcinomas accounted for $25 \%$ of LCs but by 2010s the proportion had increased to over $40 \%{ }^{(2)}$. 
SCC and SCLC generally arise from relatively proximal airways, while adenocarcinomas originate from the peripheral airways. This condition has been explained by the altered manufacturing process of the cigarettes which includes addition of filter tips, ventilation holes and other modifications. As a result of these changes, breath volume may increase, causing a shift from central deposition of tobacco smoke to peripheral regions. Incidence has differed by gender, with overall rates decreasing among male population since 1980s and increasing among female population starting from the late 1990s ${ }^{(2,3)}$. Adenocarcinomas generally grow more slowly and form smaller masses than the other subtypes. However, they tend to form metastases widely at an early stage. Adenocarcinomas develop from mucus-producing cells in the lining of the airways such as type II pneumocytes and/or Clara cells ${ }^{(2,5,7)}$. The most commonly used immunhistochemical pneumocyte markers are napsin A and thyroid transcription factor-1 (TTF1). Napsin A is an aspartic proteinase which is involved in the maturation of surfactant protein B and expressed in mainly type II pneumocytes, as well as in the epithelium of proximal and convoluted tubules of the kidney. It is a marker which uptakes granular cytoplasmic staining ${ }^{(5)}$. TTF1 is a nuclear transcription factor necessary for the development of thyroid and pulmonary tissue. It is expressed in all types of thyroid carcinomas and in most cases of lung carcinomas ${ }^{(2,5,7)}$.

Among the adenocarcinomas, most lepidic and papillary patterns demonstrate TTF1 positivity, whereas positivity is less common in solid pattern. It is worth noting that TTF1 is also expressed in other lung tumors such as SCLC, large-cell neuroendocrine carcinoma, and some carcinoid tumors. In addition these markers may be expressed by some other tumor types. For example TTF1 was detected in thyroid carcinomas and napsin A in renal cell carcinomas ${ }^{(2)}$. According to the 2015 WHO classification, adenocarcinomas have the lepidic, acinar (including the cribriform pattern), papillary or micropapillary, solid, mucinous, colloid, fetal, and enteric subtypes (Figure 1). Lepidic-predominant adenocarcinoma consists of a cellular proliferation of pneumocytes along the surface of the alveolar walls. These tumors originate from type II pneumocytes or Clara cells which are the main cells of bronchial epithelium that act as stem cells. Acinar pattern is the most typical adenocarcinoma with glandular structures and it includes the cribriform pattern. Papillary pattern is characterized by tumor cells growing in papillary fashion with central fibrovascular cores. Solid adenocarcinoma consists of sheets of tumor cells with abundant eosinophilic cytoplasm that is reminiscent of SCC. Invasive mucinous adenocarcinoma has been introduced as a new category in the WHO 2015 classification, because of distinct clinical, radiological, pathological and genetic features. The tumor was formerly called as mucinous bronchioalveolar carcinoma. Tumor cells show a goblet and/or columnar cell morphology with abundant intracellular mucin and inconspicuous nuclear atypia. In up to $90 \%$ of the cases with this subtype frequently KRAS mutation has been demonstrated. On the contrary, adenocarcinomas in which abundant mucin pools replace air spaces are called colloid adenocarcinomas. Colloid adenocarcinomas generally express intestinal markers such as CDX2, MUC2 and CK20. Interestingly, TTF1, CK7 and napsin A can be focally and weakly expressed. Fetal adenocarcinoma is similar to fetal lung and it is generally a low grade

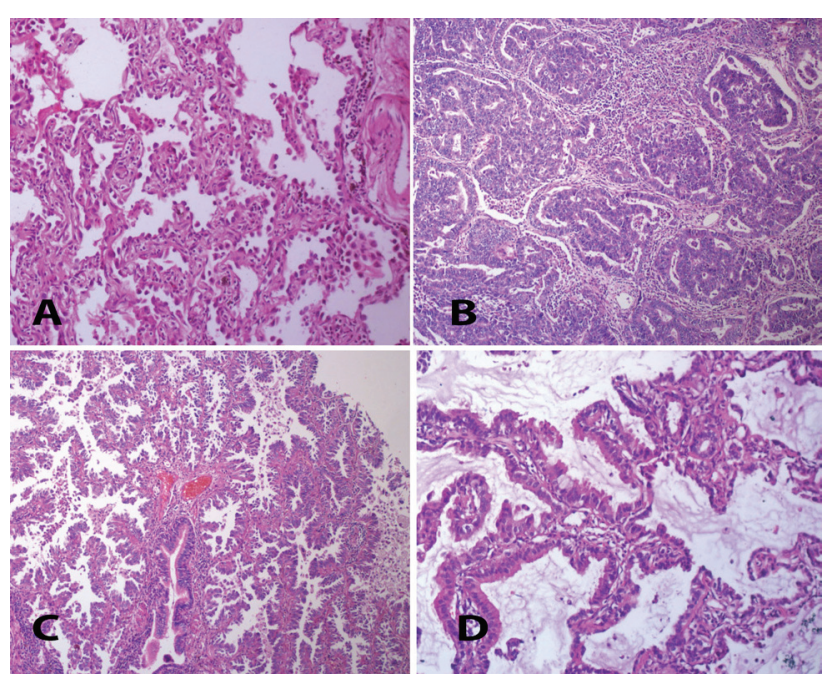

Figure 1. Several patterns of adenocarcinomas A) lepidic pattern (HE X 200) B, acinar pattern (HEx100), C) papillary pattern (100x $\mathrm{HE}$ ), and D) colloid pattern (200x HE). 
tumor. Lastly, enteric adenocarcinoma is an adenocarcinoma resembling colorectal carcinomas ${ }^{(2)}$.

Squamous cell carcinoma (SCC) is a malignant epithelial tumor that either shows keratinization and/ or intercellular bridges, or it is a morphologically undifferentiated non-small cell carcinoma that expresses immunohistochemical markers of squamous cell differentiation such as P40, p63, and some specific cytokeratins (CK5/6, CK1, CK5, CK10, CK14). P63 is a homolog of p53 which is consistently expressed by basal/stem cells of stratified epithelium and myoepithelial cells of breast and salivary gland ${ }^{(2,6)}$. Squamous dysplasia is a precursor lesion of SCC which is detected in individuals with heavy tobacco exposure and can occur as single or multifocal lesions in the bronchial epithelium. Squamous dysplasia and carcinoma in situ are part of spectrum of recognizable histopathological changes of the tracheabronchial tree. Both keratinizing and non-keratinizing SCCs usually arise from a main or lobar bronchus. SCCs generally show solid nodular or anastomotic trabecular invasive growth pattern with peripheral palisading. The tumor cells are relatively small with monomorphic cuboidal or fusiform configuration and moderately hyperchromatic nuclei. Nuclei have finely granular or vesicular chromatin pattern. Generally nucleoli are absent. Cytoplasm is scant but well defined and contrary to SCLC, nuclear molding is absent ${ }^{(2,3,5-7)}$. In 2015 WHO classification, SCC has also been reclassified into keratinizing, nonkeratinizing, and basaloid subtypes which demonstrate strongly positive squamous immunophenotype. Rarely, in undifferentiated carcinomas, translocations of NUTM1 gene are detected which express NUT protein as revealed in immunohistochemical analyses. These undifferentiated carcinomas also have morphological features in common with basaloid carcinomas, but they differ in their clinical profiles. This novel category of NUT carcinoma is considered as a different entity from $\mathrm{SCC}^{(1,2,5-7)}$.

According to the WHO 2015 classification of LCs, neuroendocrine tumors belong to a distinct family of tumors sharing some similar characteris- tics. One of them is small-cell carcinoma which is also named as SCLC. It is a malignant epithelial tumor that consists of small cells with scant cytoplasm, poorly defined cell borders and finely dispersed nuclear chromatin and absence of nucleoli. Diagnosis of SCLC can be based on routine histological evaluation, but IHC may be required for the confirmation of the neuroendocrine and epithelial nature of the tumor. High-molecular weight cytokeratins (CK1, CK5, CK10 and CK14) are not expressed in pure SCLC. A panel of neuroendocrine markers including NCAM/CD56, chromogranin, synaptophysin and neurofilament aid in the differential diagnosis. SCLC accounts for approximately $10-15 \%$ of all newly diagnosed LC cases and virtually all patients are heavy smokers. SCLC is characterized by rapid doubling time, high growth fraction and early metastatic spread ${ }^{(1-3)}$. Spread of the disease is considered to be the main prognostic factor and the majority of the patients are diagnosed during advanced stage of the disease with metastases commonly observed in the contralateral lung and distant organs ${ }^{(4)}$. Patients with locally confined disease are generally treated with platinum-based chemotherapy in combination with radiotherapy, which achieves cure rates ranging between 15 , and 20 percent. In recent years, the only advances in the management of SCLC have been in the field of radiotherapy where chest and prophylactic cranial irradiation have been demonstrated to increase survival significantly ${ }^{(2,6)}$. For advanced

Table 2. Major genetic alterations in small cell lung carcinomas.

\begin{tabular}{lcc}
\hline Alterations & Mode & Percentage \\
\hline TP53 & inactivation & 100 \\
RB1 & Inactivation & 100 \\
CREBBP & Mutation & 18 \\
EP300 & Mutation & 18 \\
MLL & Mutation & 10 \\
PTEN & Mutation & 10 \\
SLIT2 & Mutation & 10 \\
EPHA7 & Mutation & 5 \\
FGFR1 & Amplification & 6 \\
MYCL & Amplification & 16 \\
E2F2 & Amplification & 5 \\
CCN2 & amplification & 5 \\
& & \\
\hline
\end{tabular}

(*) The table is copied from "2015 WHO classification of Lung tumors", the reference 2. 
stage patients, chemotherapy was used alone. Despite high rates of initial responses to chemotherapy, patients inevitably develop drug resistance and relapse, sometimes rapidly, and succumb to the disease at a median of 10 to 12 months after diagnosis ${ }^{(1,2,5)}$. Twoyear survival rates for these patients are less than 5 percent. Although many genomic alterations have been identified in SCLC, therapeutic targets have not been achieved yet (Table 2).

\section{Major molecular alterations in lung cancers}

LCs may contain many genetic abnormalities, but only driver mutations are essential for tumor- cell survival ${ }^{(2)}$. The discovery of cancer-related driver molecular abnormalities have led to the development of efficient targeted therapies. Recent advances in understanding of the complex biology of LC, particularly of the activation of oncogenes by EGFR, KRAS, BRAF, ERBB2 mutations, ALK, ROS1, RET translocations or MET, FGFR1 amplifications in some LCs, have led to discovery of new targeted therapies ${ }^{(1,2,8-}$ 14). For this reason, biopsy specimens should be analyzed not only for diagnostic studies, but also maximum amount of tissue should be reserved for molecular studies. In addition, cell blocks should be prepared from cytology samples which are suitable for IHC or molecular analysis ${ }^{(2)}$.

In the previous studies, many of the major driver alterations have been demonstrated mainly in LCs in never- smokers and light smokers, while others are found more often in LCs of smokers (Table 3). In addition, most of these alterations are also detected in adenocarcinomas. For example, many of the major receptor tyrosine kinase-targetable driver alterations such as EGFR mutations and ALK, RET, ROS1 translocations are found mainly in adenocarcinomas of never or light-smokers, while other important alterations such as KRAS and BRAF mutations are found more often in adenocarcinomas of smokers ${ }^{(2,10,15-19)}$. However these associations are not certain, so smoking history or tumor subtype should not be used to exclude patients from molecular tests performed for specific alterations ${ }^{(1,2)}$.
Table 3. Major genetic alterations in lung tumors.

\begin{tabular}{lccc}
\hline Alteration & $\begin{array}{c}\text { Small cell } \\
\text { carcinoma } \\
(\boldsymbol{\%})\end{array}$ & $\begin{array}{c}\text { Adenocarcinoma } \\
(\boldsymbol{\%})\end{array}$ & $\begin{array}{c}\text { Squamous cell } \\
\text { carcinoma }\end{array}$ \\
\hline Mutations & & & \\
BRAF & 0 & $<5$ & 0 \\
EGFR & & & \\
Caucasian & $<1$ & $10-20$ & $<5$ \\
Asian & $<5$ & $35-45$ & $<1$ \\
ERBB2/ HER2 & 0 & $<5$ & 0 \\
KRAS & & & \\
Caucasian & $<1$ & $15-35$ & $<5$ \\
Asian & $<1$ & $5-10$ & $<5$ \\
PIK3CA & $<5$ & $<5$ & $5-15$ \\
RB & $>90$ & $5-15$ & $5-15$ \\
TP53 & $>90$ & $30-40$ & $50-80$ \\
Amplification & $<1$ & $5-10$ & 10 \\
EGFR & $<1$ & $<5$ & $<1$ \\
ERBB2/HER2 & $<1$ & $<5$ & $<5$ \\
MET & $<0-30$ & $5-10$ & $5-10$ \\
MYC & $<1$ & $<5$ & $15-25$ \\
FGFR1 & & & \\
Gene rearrangement & 0 & 5 & $<1$ \\
ALK & 0 & $1-2$ & 0 \\
RET & 0 & $1-2$ & 0 \\
ROS1 & 0 & $<1$ & 0 \\
NTRK1 & 0 & $<1$ & \\
NRG1 & & & \\
& & & \\
\hline
\end{tabular}

(*) The table is copied from "2015 WHO classification of Lung tumors", the reference 2 .

Four tyrosine kinase receptors, namely HER-1 (EGFR), HER-2/neu (ERBB2), HER-3 (ERBB3), and HER-4 (ERBB4) belong to the epidermal growth factor receptor (ERBB ) family ${ }^{(10,12,14)}$. Subsequent to ligand-binding, EGFR receptors homo- and heterodimerize and induce autophosphorylation of the intracellular tyrosine kinase domain. Thereafter molecular cascade of events involving in growth, cell proliferation, differentiation, and survival are triggered (10-16). Cetuximab, panitumumab, zalutumumab, nimotuzumab, and matuzumab are examples of monoclonal antibodies produced against EGFR receptors ${ }^{(14)}$. The extracellular ligand binding domain is blocked by these monoclonal antibodies which prevent affinity of signal molecules to these binding sites, with ensuing activation of tyrosine kinase. Alternatively, small molecules are used to inhibit the EGFR tyrosine kinase localized on the cytoplasmic side of the receptor. Small-molecule receptor tyrosine kinase inhibitors (TKIs) bind to the intracellular 
catalytic domain of the tyrosine kinase and inhibit receptor autophosphorylation and activation of downstream signaling pathways by competing with adenosine triphosphate (ATP) ${ }^{(8)}$. As a sine qua non principle, EGFR must activate itself for binding to downstream adaptor proteins. However in the absence of kinase activity, activation of EGFR is hindered with resultant blockade of the signaling cascade in cells that depend on this pathway for growth leading to decrease in tumor proliferation and migration. Among small-molecule reversible EGFR-TKIs, gefitinib, erlotinib, and lapatinib (mixed EGFR and ERBB2 inhibitor) have been most prevalently studied in patients with metastatic NSCLC ${ }^{(9)}$. Patients have been divided into EGFR-positive and EGFRnegative cases, based on a mutation (if any) demonstrated in histological test. EGFR-positive patients have shown a $60 \%$ response rate, which exceeds the response rate for conventional chemotherapy ${ }^{(2,8-17)}$. Mutations associated with enhanced sensitivity to EGFR-TKIs are found in exons 18-21 of the TK domain of EGFR ${ }^{(14)}$. Short deletions in exon 19, clustered around the aminoacid residues n747-750 and a specific exon 21 mutation (L858R) have been reported to comprise up to $90 \%$ of all activating mutations $(2,14)$. The sensitivity to small- molecule EGFR inhibitors is greatest with the L858R mutations and the exon 19 deletions. Most exon 20 insertions are resistant to these drugs ${ }^{(2)}$. However, many patients develop resistance and two primary sources of secondary resistance are the acquisition of the T790M mutation and the amplification of MET or ERBB2 oncogenes (2,10,10-12). Somatic activating ERBB2/HER2 mutations, both exon 20 insertions and extracellular domain mutations, occur in about 1-5\% of the cases with lung adenocarcinomas. Previous studies suggested that ERBB2 inhibitors could be effective but appropriate clinical data are still unsatisfactory to make such a suggestion $^{(2)}$.

Treatment with EGFR-TKIs will not elicit response in most of the unselected cases with NSCLC. At the beginning, the highest degree of clinical benefit was thought to be gained from EGFR-T1s by patients of Asian ethnicity, female patients, never-smokers, or those with adenocarcinoma histology ${ }^{(2,11-13)}$. Until the discovery of activating mutations in exons 18, 19, and 21 of the EGFR gene in the year 2004, the marker sensitive to EGFR-TKIs was not identified ${ }^{(10)}$. Most of the mutations are either point mutations leading to the formation of amino acid substitutes (exons 18 and 21) or in-frame deletions (exon 19) which are localized around the ATP-binding pocket of the intracellular tyrosine kinase domain ${ }^{(13)}$. EGFR activating gene mutations are found more commonly in adenocarcinomas but it is not so much prevalent in successively. As demonstrated in a recent study, pure SCCs do not contain EGFR mutations, on the contrary they appear only in mixed adenosquamous carcinomas ${ }^{(2)}$. Though the patients devoid of EGFR activating mutations respond poorly to treatment with EGFR TKIs, recent data substantiate use of EGFR TKIs for the sophisticated treatment of wild type patients ${ }^{(10-13)}$. Somatic EGFR mutations are observed in approximately $10-20 \%$ of lung adenocarcinomas of the patients of European descent, and in roughly $50 \%$ of adenocarcinomas in patients of East Asian origin ${ }^{(2,16)}$. These rates vary depending on local smoking incidence rates. Areas with higher smoking rates have lower rates of EGFR-and higher rates of KRAS- mutated cancers ${ }^{(2,10)}$. In patients with an EGFR-activating gene mutation, there is ample evidence to recommend first-line EGFR-TKI based treatment to achieve improved progression-free survival and overall survival compared with cytotoxic chemotherapy ${ }^{(8-19)}$.

KRAS mutation is one of the most frequent molecular abnormalities found in NSCLC. It is also the most common receptor tyrosine kinase/RAS/RAF pathway oncogenic driver alteration in lung adenocarcinomas. RAS proteins are GTP kinases, discovered in 1960s, whose GTP- RAS active isoform stimulates several pathways involved in cellular growth. V-Ki-ras2 Kirsten rat sarcoma viral oncogene homologue (KRAS) mutations are found in nearly $25-35 \%$ of NSCLC, with a higher proportion in the adenocarcinoma subtype ${ }^{(2,11,18,20,21)}$. Among KRAS mutations, G12C, G12V, G12D, G12A, other G12 and G13 
mutations are diagnosed in approximately 40, 21, 17, 10 and $12 \%$ of the cases, respectively ${ }^{(18)}$. Smoking history effects the molecular profile of NSCLC. Incidence rates of KRAS mutations reach to $25-35 \%$ in smokers and only $5 \%$ in nonsmokers ${ }^{(18)}$. Type of KRAS mutation is related to prior smoking history. In never-smokers, the most common KRAS mutation is $\mathrm{G} 12 \mathrm{D}(56 \%)$, and $\mathrm{G} 12 \mathrm{C}$ is the most frequent mutation among former and current smokers (41\%). Since somatic KRAS mutations are observed in approximately $30 \%$ of the Caucasian patients, and $10 \%$ of the patients with East Asian descent, KRAS mutations are also ethnicity-driven ${ }^{(2,18)}$. KRAS and EGFR mutations develop independently from each other, and EGFR-mutated NSCLC has better prognosis, while KRAS mutations detected in NSCLC seem to be associated with poorer prognosis. Other molecular abnormalities related to activation of RAS pathway are diagnosed in $25 \%$ of NSCLC cases, including EGFR (10-23\%), BRAF (2\%), HER2 (1\%) and NRAS (0.2\%) mutations, and MET amplifications $(2 \%)$ in respective percentages of patients. Controversies exist about negative prognostic value of KRAS mutations, and their adverse effects on standard chemotherapy and targeted therapies. Many medications have been developed particularly for the treatment of KRAS-mutated NSCLC patients. Clinical efficacy could not be achieved by directly inhibiting RAS activation. Inhibition of downstream targets of the mitogen-activated protein kinase (MEK) pathway is a promising strategy ${ }^{(20,21)}$. In summary, incidence of KRAS mutations increases in cases with adenocarcinoma, smokers and Caucasian patients and KRAS mutations are associated with lack of response to EGFR-targeted agents in lung adenocarcinoma, but their impact on overall survival remains controversial. Unfortunately there are no demonstrably efficacious treatment for KRAS-mutant lung adenocarcinomas at present ${ }^{(2,21)}$.

Mutations in the BRAF gene are determined in $2-10 \%$ of the cases with lung adenocarcinomas. The incidence of V600E mutations in lung adenocarcinomas is lower than in other malignancies such as mela- noma and colorectal cancers. Unfortunately any BRAF inhibitor is not currently approved for the treatment of lung adenocarcinomas ${ }^{(2)}$.

In humans anaplastic lymphoma kinase (ALK) (also known as ALK tyrosine kinase receptor or CD246) which is encoded by the ALK gene has been identified. ALK displays its effects on specific neurons in the nervous system, and also has an important place in the development of the brain. The analysis of amino acid sequences has revealed that ALK receptor tyrosine kinase contains both transmembrane and extracellular domains. This gene was firstly determined in anaplastic large-cell lymphomas (ALCLs). The 2.5 chromosomal translocation is associated with approximately $60 \%$ of ALCLs. As a result of translocation, a fusion gene consisting of the ALK and the nucleophosmin (NPM) genes is formed. From chromosome 2 the 3 ' half of ALK is derived which encodes the catalytic domain, and fuses to the 5 ' portion of NPM from chromosome 5. The product of the NPM-ALK fusion gene has oncogenic properties. Activated ALK gene rearrangements are seen in $3-7 \%$ of the cases with lung adenocarcinomas. Cells of lung adenocarcinomas characteristically harbors an abnormal configuration of DNA where fusion of echinoderm microtubule-associated protein-like 4 (EML4) gene to the ALK gene occurs. EML4-ALK which is found in many cases with LC is the product of this abnormal gene fusion, and has important functions in the promotion, and maintenance of the malignant behavior of the cancer cells. The transforming

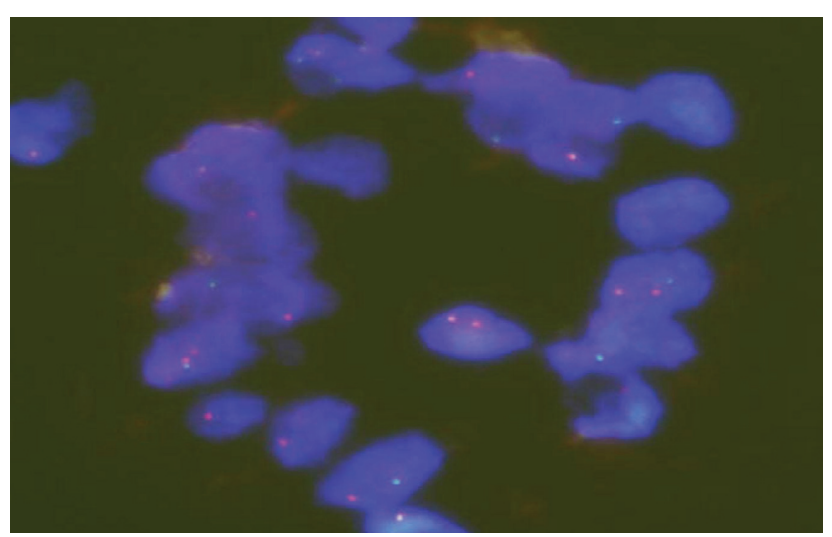

Figure 2. ALK gene rearrangement in a lung adenocarcinoma by FISH. 
EML4-ALK fusion gene which is responsible for approximately $3-5 \%$ of the cases of NSCLC was first reported in $2007^{(22)}$. The vast majority of cases are adenocarcinomas. The standard test used to detect this gene in tumor samples is fluorescence in situ hybridization (FISH) applied using a US FDA approved kit (Figure 2). ALK lung cancers are found in patients of all ages although on average these patients tend to be younger. Although ALK lung cancers are more frequently seen in light cigarette smokers or nonsmokers, considerable number of current or former cigarette smokers are victims of this malignancy. EGFR-or KRAS-mutated tumors have not EML4ALK-rearrangement seen in NSCLC ${ }^{(2,22-24)}$. Patients whose tumors harbor ALK rearrangement respond well to the ALK/MET/ROS1 inhibitor crizotinib (2).

Activation of the ROS1, and RET genes by fusion with several possible partner genes, is seen in approximately $1 \%$ of the patients with lung adenocarcinomas. Both events are almost exclusively detected in non-smokers ${ }^{(2)}$.

Recent studies have suggested that SCLC is a heterogeneous disease characterized by genomic alterations targeting a broad variety of genes, including those involved in the regulation of transcription and modification of chromatin which seems to be a hallmark of this specific LC subtype ${ }^{(25)}$. SCLC is characterized by genomic instability and very high mutation load consistent with long-term exposure of cellular DNA to the effects of the carcinogens found in tobacco smoke ${ }^{(2,25,26)}$. The typical alterations found in SCLC are nearly uniform loss of function of the tumor suppressors TP53 and RB1 ${ }^{(2,25)}$. In addition, a high frequency of deletions in chromosome $3 p$, which contains several tumor suppressor genes, has been reported ${ }^{(25)}$. Loss of TP53, found in $75-90 \%$ of the patients, could represent an important early event in SCLC tumorigenesis. The p53 protein has been described as "the guardian of the genome" because of its crucial role in maintaining genomic integrity after DNA damage by inducing cell cycle arrest or apoptosis and regulating the activity of DNA repair mechanisms ${ }^{(26)}$. Moreover, recent studies have highlighted roles for p53 in modulating many other cellular processes, including metabolism, stem cell maintenance, invasion and metastasis, as well as communication within the tumor microenvironment ${ }^{(2,25,26)}$.

The retinoblastoma (RB1) gene is a tumor suppressor gene firstly identified in retinoblastoma, and inactivated in nearly all SCLCs ${ }^{(2,25,26)}$. The product of this gene is a protein that plays an important role in the regulation of the cell cycle (mainly in transition from $\mathrm{G} 1$ to $\mathrm{S}$ phase), apoptosis and cellular differentiation ${ }^{(25)}$. Loss of RB1 has been also associated with up-or down-regulation of several important genes such as enhancer of zeste 2 (EZH2), Oct4 and SOX2. Amplified SOX2 was firstly characterized as a driver oncogene in squamous lung cancer ${ }^{(25)}$. SOX2 is a member of a large family of transcription factors involved in the maintenance of embryonic stem cells, induction of pluripotent stem cells and lung development, and when overexpressed, it induces development of various tumors, including SCLC (2).

MYC is another amplified gene found in 20-30\% of the cases with SCLC ${ }^{(25)}$. The MYC family proteins, MYC, MYCN and MYCL, are transcriptional factors activated by numerous upstream intracellular pathways to regulate expression of a large number of genes involved in cell cycle and cell growth ${ }^{(2,25)}$. The precise role of MYC in the development or progression of SCLC is not fully understood, however its role in the control of pluripotency, self-renewal, and epithelial-to-mesenchymal transition (all processes involved in neoplastic transformation) is well recognized. The phosphatidylinositol-3-kinase (PI3K)/ AKT/mTOR signaling pathway, which regulates cell proliferation and growth as well as many other cellular functions, is commonly deregulated in several cancer types. Therefore, the pathway has been largely exploited for cancer drug discovery ${ }^{(25)}$. The constitutive activation of the PI3K/AKT/mTOR pathway is also observed in a significant percentage of SCLC cases, as a result of alterations affecting key genes in the pathway including deletions of PTEN, PIK3CA mutations, or mTOR overexpression ${ }^{(2)}$. In addition, inactivating mutations in $\mathrm{NOTCH}$ family genes have 
been identified by whole-genome sequencing in $25 \%$ of human SCLC tumors, suggesting that these alterations may represent a major feature of SCLC ${ }^{(25)}$. NOTCH signaling is critical in the regulation of the neuroendocrine compartment size in the maturaation of lung and its inactivation could therefore contribute to malignant transformation of neuroendocrine cells (2,27-30).

Recently, tremendous developments have been achieved in understanding of cancer immunology . The complex relationships between tumor cells, tumor microenvironment and immune system cells, especially the cytotoxic and helper $\mathrm{T}$ cells and the regulatory $\mathrm{T}$ cells are beginning to be elucidated. Programmed cell death protein 1 (PD-1), also known as CD279, is a protein encoded by the PDCD1 gene. PD-1 is a cell surface receptor that belongs to the immunoglobulin superfamily which is expressed on $\mathrm{T}$ cells and pro-B cells. It functions as an immune checkpoint, plays an important role in down- regulation of the immune system by preventing activation of T-cells, which in turn weakens autoimmunity and promotes self-tolerance. Its inhibitory effect is accomplished through a dual mechanism which involves promoting apoptosis in antigen specific T-cells in lymph nodes and the reducing apoptosis in regulatory $\mathrm{T}$ cells. Its ligands are PDL1 and PDL2. Currently it has been determined that the immune checkpoint inhibitors targeting PD-1 or PD-L1 can reduce the tumor's growth and they can be used in the treatment of several cancers. Recently, NSCLC has been defined as an immunogenic tumor type, and several breakthroughs in immunotherapies have led to rapid expansion of the use of PDL1 inhibitors such as nivolumab and pembrolizumab ${ }^{(2,31)}$.

\section{CONCLUSION}

Smoking induces numerous adverse health effects. It has been previously determined that smoking is causally connected to cancers of the lung and upper aerodigestive tract ${ }^{(2,6)}$. In contrast to some other tumors, few advances have been made in systemic treatment of LC in recent years, especially in SCLC. Since this aggressive cancer is usually diagnosed at unresectable stages, only small biopsy and/or cytology specimens, insufficient for histopathological and/or cytological identification complicates differential diagnosis of LC. Recent advances have shown that the most important factors in tumorigenesis of LCs are EGFR, KRAS, BRAF, ERBB2, ALK, ROS1, RET, MET, and FGFR1, as well as PD-1 and PDL-1. This knowledge has led the way to the discovery of new targeted therapies ${ }^{(1,2)}$. For this reason, biopsy specimens should not be used only for diagnosis, but also maximum amount of tissue should be available for molecular studies. In addition, cell blocks should be prepared from cytology samples which are suitable for IHC or molecular analysis. In some studies, it has been demonstrated that many major driver alterations are found mainly in LCs of never-smokers and light smokers; while others are found more often in LCs of smokers. Because of conflicting results, smoking history or tumor subtype should not be used to exclude patients from molecular testing performed to detect specific alterations ${ }^{(1,2)}$.

\section{REFERENCES}

1. Rothschild SI. Targeted Therapies in Non-Small Cell Lung Cancer-Beyond EGFR and ALK. Cancers (Basel) 2015;7(2):930-49. doi: 10.3390/ cancers7020816.

2. Travis WD, Brambilla E, Burke AP, Marx A, Nicholson AG. WHO classification of tumours of the lung, pleura, thymus and heart. International Agency for Research on Cancer (IARC). $4^{\text {th }}$ Ed. Lyon 2015.

3. Lewis DR, Check DP, Caporaso NE, Travis WD, Devesa SS. US lung cancer trends by histologic type. Cancer 2014;120(18):2883-92. https://doi.org/10.1002/cncr.28749

4. Yano T, Miura N, Takenaka T, Haro A, Okazaki H, Ohba T, et al. Never-smoking non-small cell lung cancer as a separate entity: clinicopathologic features and survival. Cancer 2008;113(5):1012-8. https://doi.org/10.1002/cncr.23679

5. Reynolds SD, Malkinson AM. Clara Cell: Progenitor for the bronchiolar epithelium. Int $J$ Biochem Cell Biol 2010;42(1):1-4. https://doi.org/10.1016/j.biocel.2009.09.002

6. Rossi G, Cavazza A. Pulmonary neoplasms. In Sternberg' surgical pathology. Eds: 2015: 1160-1206.

7. Chang CM, Corey CG, Rostron BL, Apelberg BJ. Systematic review of cigar smoking and all cause and smoking related mortality. BMC Public Health 2015;15:390. 
https://doi.org/10.1186/s12889-015-1617-5

8. Bazley LA, Gullick WJ. The epidermal growth factor receptor family. Endocr Relat Cancer 2005;12(Suppl 1):S17-27. https://doi.org/10.1677/erc.1.01032

9. Hsieh AC, Moasser MM. Targeting HER proteins in cancer therapy and the role of the non-target HER3. Br J Cancer 2007;97(4):453-7. https://doi.org/10.1038/sj.bjc.6603910

10. Mendelsohn J, Baselga J. Epidermal growth factor receptor targeting in cancer. Semin Oncol 2006;33(4):369-85. https://doi.org/10.1053/j. seminoncol. 2006.04.003.

11. Jackman DM, Miller VA, Cioffredi LA, Yeap BY, Jänne PA, Riely GJ, et al. Impact of epidermal growth factor receptor and KRAS mutations on clinical outcomes in previously untreated non-small cell lung cancer patients: results of an online tumor registry of clinical trials. Clin Cancer Res 2009;15(16):5267-73. https://doi.org/10.1158/1078-0432.CCR-09-0888

12. Liu HB, Wu Y, Lv TF, Yao YW, Xiao YY, Yuan DM, Song Y. Skin rash could predict the response to EGFR tyrosine kinase inhibitor and the prognosis for patients with non-small cell lung cancer: a systematic review and meta-analysis. PLoS ONE 2013;8(1):e55128. https://doi.org/10.1371/journal.pone.0055128

13. Ellison G, Zhu G, Moulis A, Dearden S, Speake G, McCormack R. EGFR mutation testing in lung cancer: a review of available methods and their use for analysis of tumour tissue and cytology samples. J Clin Pathol 2013;66(2):79-89. https://doi.org/10.1136/jclinpath-2012-201194

14. Paez JG, Janne PA, Lee JC, Tracy S, Greulich H, Gabriel S, Herman P, Kaye FJ, Lindeman N, Boggon TJ. EGFR mutations in lung cancer: Correlation with clinical response to gefitinib therapy. Science 2004;304:1497-1500. https://doi.org/10.1126/science.1099314

15. Lynch TJ, Bell DW, Sordella R, Gurubhagavatula S, Okimoto RA, Brannigan BW, et al. Activating mutations in the epidermal growth factor receptor underlying responsiveness of non-small-cell lung cancer to gefitinib. $N$ Engl $\mathrm{J}$ Med 2004;350(21):2129-39. https://doi.org/10.1056/NEJMoa040938

16. Wu YL, Zhou C, Hu CP, et al. Afatinib versus cisplatin plus gemcitabine for first-line treatment of Asian patients with advanced non-small-cell lung cancer harbouring EGFR mutations (LUX-Lung 6): an open-label, randomised phase 3 trial. Lancet Oncol 2014;15:213-22.

https://doi.org/10.1016/S1470-2045(13)70604-1

17. D'Angelo SP, Pietanza MC, Johnson ML, et al. Incidence of EGFR exon 19 deletions and L858R in tumor specimens from men and cigarette smokers with lung adenocarcinomas. $J$ Clin Oncol 2011;29:2066-70. https://doi.org/10.1200/JCO.2010.32.6181

18. Rekhtman N, Paik PK, Arcila ME, et al. Clarifying the spectrum of driver oncogene mutations in biomarker-verified squamous carcinoma of lung: lack of EGFR/KRAS and presence of PIK3CA/AKT1 mutations. Clin Cancer Res 2012;18:1167-76.

https://doi.org/10.1158/1078-0432.CCR-11-2109

19. Camidge DR, Bang YJ, Kwak EL, Iafrate AJ, Varella-Garcia
M, Fox SB, et al. Activity and safety of crizotinib in patients with ALK-positive non-small-cell lung cancer: updated results from a phase 1 study. Lancet Oncol 2012;13(10):1011-9. https://doi.org/10.1016/S1470-2045(12)70344-3

20. Martin P, Leighl NB, Tsao MS, Shepherd FA. KRAS mutations as prognostic and predictive markers in non-small cell lung cancer. J Thorac Oncol 2013;8(5):530-42. https://doi.org/10.1097/JTO.0b013e318283d958

21. Kempf E, Rousseau B, Besse B, Paz-Ares L. KRAS oncogene in lung cancer: focus on molecularly driven clinical trials. Eur Respir Rev 2016;25(139):71-6. https://doi.org/10.1183/16000617.0071-2015

22. Soda M, Choi YL, Enomoto M, et al. Identification of the transforming EML4-ALK fusion gene in non-small-cell lung cancer. Nature 2007;448(7153):561-6. https://doi.org/10.1038/nature05945

23. Ye M, Zhang X, Li N, Zhang Y, Jing P, Chang N, et al. ALK and ROS1 as targeted therapy paradigms and clinical implications to overcome crizotinib resistance. Oncotarget 2016;7(11):12289-304 https://doi.org/10.18632/oncotarget.6935

24. Kwak EL, Bang YJ, Camidge DR, Shaw AT, Solomon B, Maki RG, et al. Anaplastic lymphoma kinase inhibition in non-small-cell lung cancer. N Engl J Med 2010;363(18):1693703. https://doi.org/10.1056/NEJMoa1006448

25. Santarpia M, Daffinà MG, Karachaliou N, González-Cao M, Lazzari C, Altavilla G, Rosell R. Targeted drugs in small-cell lung cancer. Transl Lung Cancer Res 2016;5(1):51-70. https://doi.org/10.3978/j.issn.2218-6751.2016.01.12.

26. Mamdani H, Induru R, Jalal SI. Novel therapies in small cell lung cancer. Transl Lung Cancer Res 2015;4(5):533-44. https://doi.org/10.3978/j.issn.2218-6751.2015.07.20.

27. Derman BA, Mileham KF, Bonomi PD, Batus M, Fidler MJ. Treatment of advanced squamous cell carcinoma of the lung: a review. Transl Lung Cancer Res 2015;4(5):524-32. https://doi.org/10.3978/j.issn.2218-6751.2015.06.07.

28. West L, Vidwans SJ, Campbell NP, Shrager J, Simon GR, Bueno R, Dennis PA, Otterson GA, Salgia R. A novel classification of lung cancer into molecular subtypes. PLoS One 2012;7(2):e31906. https://doi.org/10.1371/journal.pone.0031906

29. Yang L, Zhou Y, Li Y, Zhou J, Wu Y, Cui Y, Yang G, Hong Y. Mutations of $\mathrm{p} 53$ and KRAS activate NF- $x \mathrm{~B}$ to promote chemoresistance and tumorigenesis via dysregulation of cell cycle and suppression of apoptosis in lung cancer cells. Cancer Lett 2015;357(2):520-6. https://doi.org/10.1016/j.canlet.2014.12.003

30. Liu K, Wang S, Liu Y, Gu J, Gu S, Xu Z, Zhang R, Wang Z, Ma H, Chen Y, Ji L. Overexpression of MYCN promotes proliferation of non-small cell lung cancer. Tumour Biol 2016. https://doi.org/10.1007/s13277-016-5236-2

31. Bansal P, Osman D, Gan GN, Simon GR, Boumber Y. Recent Advances in Immunotherapy in Metastatic NSCLC. Front Oncol 2016;6:239. https://doi.org/10.3389/fonc.2016.00239 